\title{
Extraperitoneal pancreas transplantation: A technical note
}

\author{
Ekstraperitoneal pankreas nakli: Teknik bir not
}

\author{
Sanem Güler Çimen ${ }^{1}$, Sertaç Çimen² ${ }^{\text {ID }}$, Eyüp Kahveci ${ }^{3}$ (D), Michele Molinari ${ }^{4}$ (ID \\ ${ }^{1}$ Department of General Surgery, Health Sciences University, Dışkapı Training and Research Hospital, Ankara, Turkey \\ ${ }^{2}$ Department of Urology and Kidney Transplantation, Health Sciences Universtiy, Dışkapı Training and Research Hospital, Ankara, Turkey \\ ${ }^{3}$ Turkish Transplant Foundation, Ankara, Turkey \\ ${ }^{4}$ University of Pittsburgh Medical Center, Pittsburgh, USA
}

\begin{abstract}
Simultaneous pancreas-kidney transplantation is the best treatment of choice for patients with type 1 diabetes and end-stage renal failure. Despite the well-known technique of kidney transplantation, there is no general consensus on the most efficient technique for pancreas transplantation. Successful outcome of pancreas transplantation largely depends on the operating surgeon's expertise and donor organ quality. However, donor organ quality is getting worse than before due to the worldwide epidemic of obesity. One aspect to improve is the surgical technique during which the organ is prepared and transplanted. In this article, we report a new surgical technique for pancreas transplantation to retroperitoneal region with enteric drainage by only a few centimeters of peritoneal violation and describe the possible advantages of this technique.

Keywords: Pancreas; pancreas transplantation; pancreatitis; rejection; surgical; technique; transplantation; type 1 diabetes; vascular thrombosis.
\end{abstract}

öz

Simultane pankreas-böbrek nakli tip 1 diyabeti ve son dönem böbrek yetmezliği olan hastalar için tercih edilen en iyi tedavidir. Böbrek nakli tekniğinin iyi bilinmesine rağmen, pankreas nakli için en etkili teknikle ilgili fikir birliği yoktur. Pankreas naklinin başarıyla sonuçlanması büyük oranda cerrahın deneyimi ve donör organ kalitesine bağlıdır. Diğer yandan, dünya çapında yaygın obezite salgını nedeniyle donör organ kalitesi giderek daha kötüleşmektedir. İyileştirilecek konulardan biri organın hazırlandığı ve nakledildiği cerrahi tekniktir. Bu yazıda, retroperitoneal bölgeye pankreas nakli için enterik drenaj ile sadece birkaç santimetrelik peritoneal ihlal içeren yeni bir cerrahi teknik ve bu tekniğin olası avantajları bildirildi.

Anahtar sözcükler: Pankreas; pankreas nakli; pankreatit; ret; cerrahi; teknik; nakil; tip 1 diyabet; vasküler tromboz.

Pancreas transplantation is the sole treatment that establishes normal glucose and glycosylated hemoglobin levels without insulin replacement in type 1 diabetic patients. ${ }^{[1]}$ The first exocrine pancreas transplantation was performed simultaneously with kidney transplantation in December 1966 in Minnesota, United States, by William Kelly and Richard Lillehei. ${ }^{[1]}$ The first isolated pancreas transplantation was performed in 1968 in Brazil by Edison Teixeria. ${ }^{[2]}$
The main objectives of pancreas transplantation are rendering the recipient independent from insulin replacement and prevention of diabetic complications. It may be performed simultaneously with kidney transplantation or pancreas after kidney transplantation (PAK) may be performed in patients whose kidneys failed due to diabetic nephropathy. Pancreas transplantation alone (PTA) is indicated in patients with recurrent acute and severe metabolic complications of diabetes such as hypoglycemia 
and ketoacidosis despite insulin-based treatment. ${ }^{[3]}$ Today, the most frequent modality of pancreas transplantation is simultaneous pancreas-kidney transplantation (75\%), followed by PAK (12\%) and PTA (7\%). ${ }^{[4]}$

According to the International Pancreas Transplant Registry database, over 35,000 pancreas transplantations were performed until the end of 2010. However, some aspects of the surgical technique such as access (intraperitoneal, retroperitoneal) and site selection for venous (portal vein, splenic vein, inferior mesenteric vein, superior mesenteric vein or external iliac vein) and exocrine (stomach, duodenum, small bowel or urinary tract) drainage differ from center to center and surgeon to surgeon. ${ }^{[3]}$

Rejection (33\%), vascular thrombosis (19\%), pancreatitis (20\%), infection (18\%), intestinal leak (8\%), fistulae (6.5\%), and hemorrhage (2.4\%) are the main complications of pancreas transplantation. ${ }^{[5]}$ These complications may lead to the loss of the graft in the first three months after transplantation. ${ }^{[6]}$

Rejection is suspected in recipients with increased serum creatinine levels, decreased amylasuria (bladder drainage), and high serum lipase levels. However, ultrasound-guided pancreatic graft biopsy is the gold standard for definitive diagnosis of rejection. ${ }^{[7]}$

Vascular thrombosis is the most common non-immunological cause of early graft failure. ${ }^{[7,8]}$ Venous thrombosis is more common than arterial thrombosis. Use of venous extension grafts increases the risk of vascular thrombosis. ${ }^{[8]}$

Intestinal leak is one of the most dangerous and possibly life-threatening complications of pancreas transplantation with enteric drainage. ${ }^{[9]}$ Prolonged ischemia time is among the most important risk factors of this complication. ${ }^{[7-9]}$ Fistula formation is another potential complication of pancreas transplantation..$^{[5,6]}$ Fistulae may form between the graft and skin or the peritoneal cavity. ${ }^{[10]}$ Pancreas transplantation recipients who underwent bladder drainage are afflicted with frequent urological and metabolic complications. ${ }^{[10]}$

In this article, we describe a new technique of pancreas transplantation with venous drainage to external iliac vein and exocrine drainage to ileum. The new aspect of this approach is that pancreatic graft is transplanted extraperitoneally with violation of only a few centimeters of peritoneum necessary to create a duodenoenteric anastomosis.

\section{SURGICAL TECHNIQUE}

Pancreatic graft is usually recovered from heart-beating deceased multi-organ donors. Backtable preparation is performed as per standard methods: The duodenal segment is shortened and the duodenal borders are sutured and invaginated. The portal vein is mobilized and a vascular ' $Y$ ' graft is reconstructed (iliac arteries from the donor with the pancreatic graft superior mesenteric artery and splenic artery) (Figure 1).

A Gibson incision is opened for retroperitoneal access and iliac fossa is exposed (Figure 2).

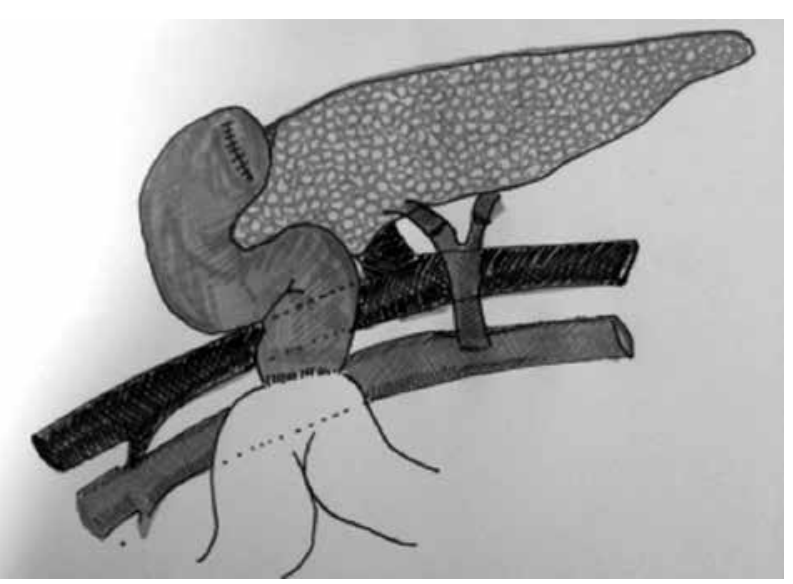

Figure 1. Configuration of vessel anastomosis.

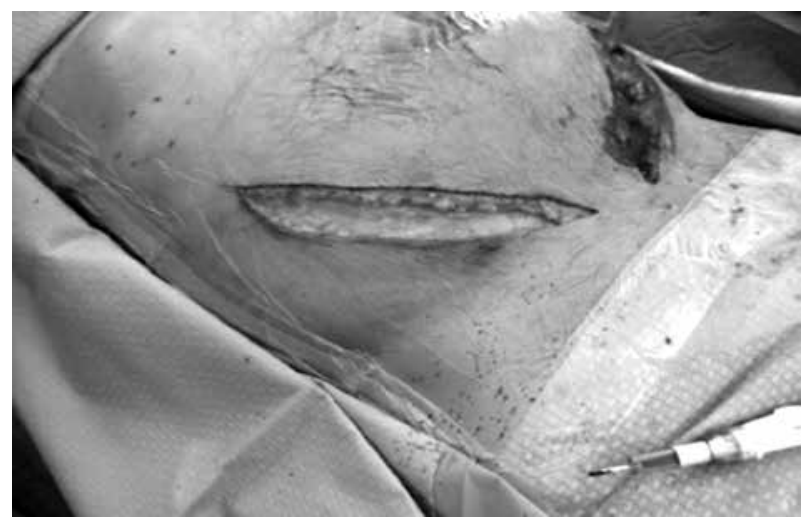

Figure 2. Bilateral Gibson incision for simultaneous kidney-pancreas transplantation (right side used for pancreatic transplantation, left side used for kidney transplantation). 
Subsequently, the common and external iliac vessels are isolated and the pancreatic graft is placed into the iliac fossa in a way that the pancreatic head is positioned caudally. The graft portal vein is anastomosed to the recipient's common or external iliac vein in an end-to-side fashion. The ' $\mathrm{Y}$ ' iliac artery graft is then anastomosed to either common or external

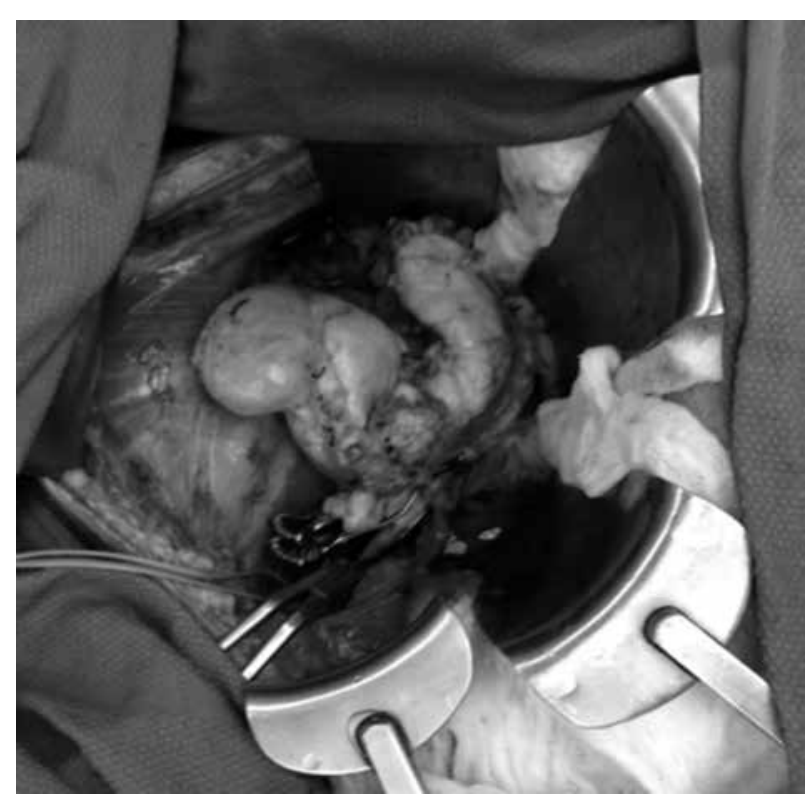

Figure 3. Pancreatic allograft pre-perfusion with bulldog clamps over ' $Y$ ' iliac artery graft and portal vein.

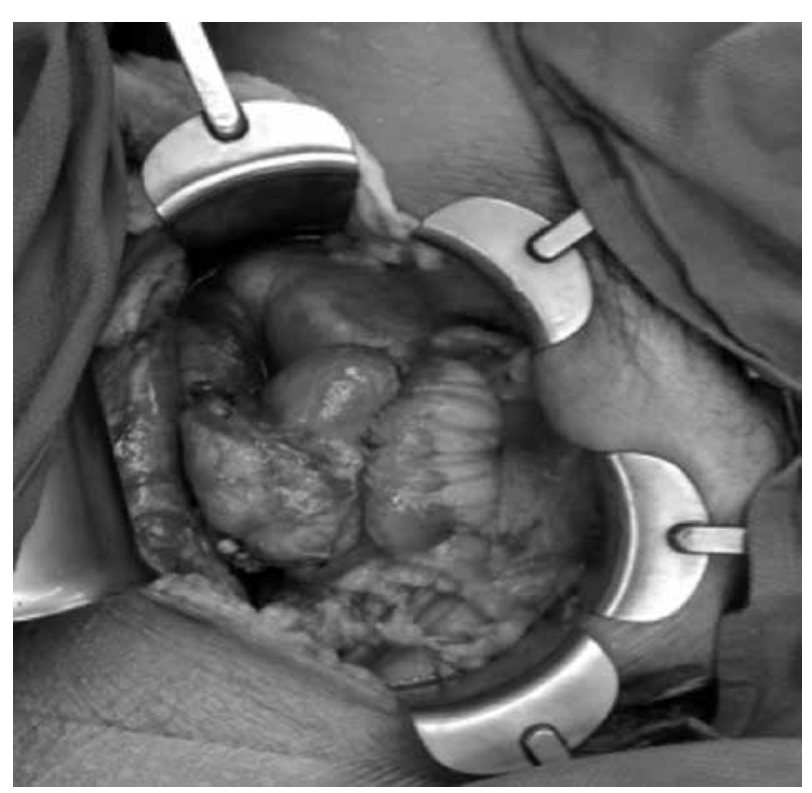

Figure 4. Pancreatic allograft post-perfusion. iliac artery in an end-to-side fashion (Figure 3). After reperfusion, a $3-4 \mathrm{~cm}$ peritoneal incision (i.e. peritoneal window) is performed in the medial aspect of the surgical field and a loop of small intestine is brought to the retroperitoneal space and anastomosed to the free surface of the donor's duodenum without a Roux-en-Y intestinal loop (Figure 4 and 5). After completion of the duodenoenteric anastomosis, the intestinal loop is repositioned in the peritoneal cavity and the suture line is approximated to the level of the peritoneal window.

\section{Advantages}

There are four main advantages of this technique.

1. There is a 3\% risk of small bowel obstruction due to adhesion formation after any intraperitoneal surgery. The pancreas transplantation technique described in this report is mainly extraperitoneal. Therefore, the risk of postoperative adhesion formation and subsequent small bowel obstruction is significantly reduced.

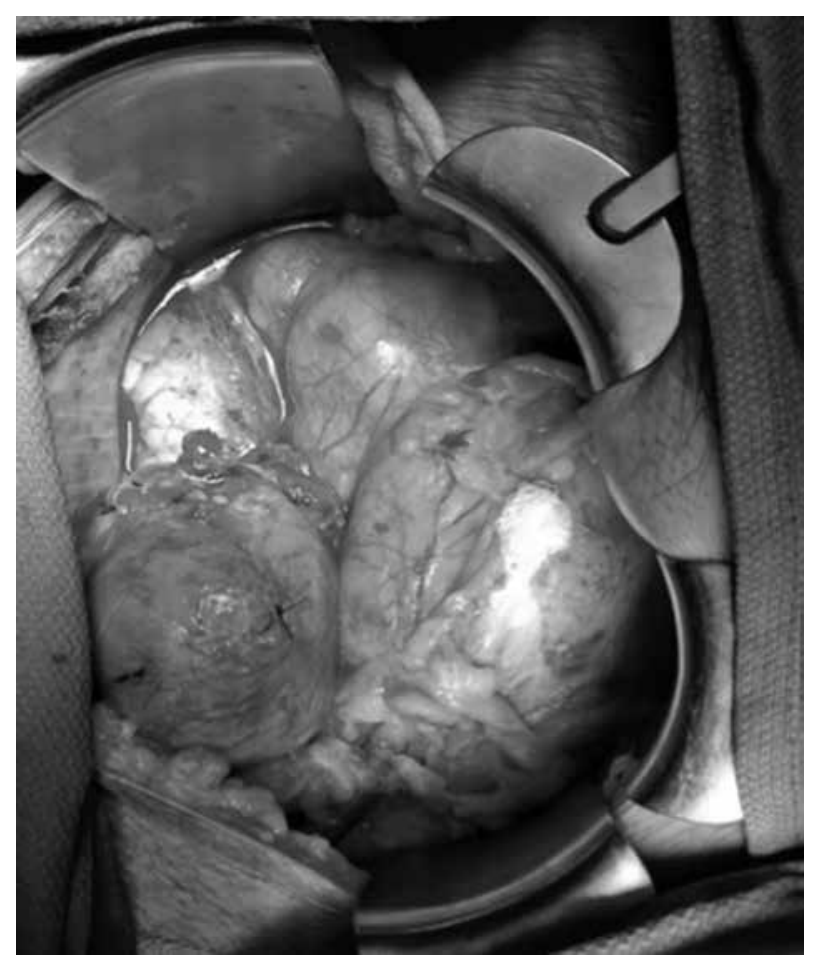

Figure 5. Duodenal segment anastomosis placed into intra-abdominal cavity and peritoneum stitched over. 
2. In the case of intraperitoneal pancreas transplantation, complications such as infection, intestinal leak or enteric fistulae can rapidly lead to intra-abdominal sepsis and require removal of the graft. However, with the help of the technique presented here, the infection focus and the graft are located in separate compartments and the graft is protected. In case of a leak or fistula, infected collections are confined by the retroperitoneal muscles and the abdominal compartment is separated from the septic process.

3. This new technique does not require a venous extension. Therefore, the risk of venous thrombosis is significantly decreased. Furthermore, in the absence of complex vascular reconstructive procedures, the cold ischemia time is relatively short. Since prolonged ischemia time is one of the most important risk factors for the development of intestinal leak, one can argue that this technique reduces the risk of intestinal leakage.

4. The pancreatic graft is more accessible in an extraperitoneal location for procedures such as ultrasound imaging and pancreatic graft biopsy.

\section{Conclusion}

Extraperitoneal pancreas transplantation technique with systemic venous and enteric exocrine drainage by opening a small peritoneal window is feasible and safe. Prospective randomized controlled studies are needed to compare its success and safety profile to its intraperitoneal counterpart.

\section{Declaration of conflicting interests}

The authors declared no conflicts of interest with respect to the authorship and/or publication of this article.

\section{Funding}

The authors received no financial support for the research and/or authorship of this article.

\section{REFERENCES}

1. Feitosa Tajra LC, Dawhara M, Benchaib M, Lefrancois $\mathrm{N}$, Martin X, Dubernard JM. Effect of the surgical technique on long-term outcome of pancreas transplantation. Transpl Int 1998;11:295-300.

2. Gruessner AC, Gruessner RW. Pancreas transplant outcomes for United States and non United States cases as reported to the United Network for Organ Sharing and the International Pancreas Transplant Registry as of December 2011. Clin Transpl 2012:23-40.

3. Hampson FA, Freeman SJ, Ertner J, Drage M, Butler A, Watson CJ, et al. Pancreatic transplantation: surgical technique, normal radiological appearances and complications. Insights Imaging 2010;1:339-47.

4. Han DJ, Sutherland DE. Pancreas transplantation. Gut Liver 2010;4:450-65.

5. Kelly WD, Lillehei RC, Merkel FK, Idezuki Y, Goetz FC. Allotransplantation of the pancreas and duodenum along with the kidney in diabetic nephropathy. Surgery 1967;61:827-37.

6. Martin X, Petruzzo P, Dawahra M, Feitosa Tajra LC, Da Silva M, Pibiri L, et al. Effects of portal versus systemic venous drainage in kidney-pancreas recipients. Transpl Int 2000;13:64-8.

7. Meirelles Júnior RF, Salvalaggio $P$, Pacheco-Silva A. Pancreas transplantation: review. Einstein (Sao Paulo) 2015;13:305-9.

8. Petruzzo P, Badet L, Lefrançois $\mathrm{N}$, Berthillot $\mathrm{C}$, Dorel SB, Martin X, et al. Metabolic consequences of pancreatic systemic or portal venous drainage in simultaneous pancreas-kidney transplant recipients. Diabet Med 2006;23:654-9.

9. Siskind E, Amodu L, Liu C, Akerman M, Stodghill $\mathrm{J}$, Wali $\mathrm{R}$, et al. A comparison of portal venous versus systemic venous drainage in pancreas transplantation. HPB (Oxford) 2018 Aug 27. pii: S1365-182X(18)32705-9.

10. Teixeira E, Monteiro G, De Cenzo M, Teixeira A, Bergan JJ. Transplantation of the isolated pancreas: report on the first human case. Bull Soc Int Chir 1970;29:337-44. 